Katarzyna Łazorko ${ }^{1}$

\title{
WORK SAFETY AS AN ELEMENT OF EXTERNAL EMPLOYER BRANDING STRATEGY
}

\begin{abstract}
The paper presents the concept of external employer branding. It includes results of study prepared by the author to research to what extend employers in Poland perceive work safety elements as the ones that should be communicated to attract prosper employees. The research was design to analyses contents of web pages dedicated to prospers employees. The largest businesses in Poland were chosen for the research as their budgets are the highest and CSR and EB performance should be of high quality. The research revealed that the aspect of work safety is not as popular issue to encourage employees as expected. Even organisations that employ large number of labourers do not mention the topic of work safety or just treat it briefly in their external employer branding communication.
\end{abstract}

Key words: Employer branding, work safety, internal marketing, talents recruitment.

\section{Introduction}

The processes of fluctuation of employees, and the need for constant recruitment and training, increase costs of every business significantly. It has become obvious that traditional tools for HR are not efficient any more. Employees has changed and so have their expectations [1]. Moreover, 2008 crisis and changes in demography has influenced labour supply level recently. The all mentioned factors can be indicated as the ones affecting the genesis of a "employer branding" (EB) concept, that combines different elements of HR, marketing, PR, and branding, to create teams of employees who are satisfied with their job the way that enables effective performance and their advocacy. Origins of the theory of employer branding may be found in the concept of internal marketing. It was indicated as one of the key elements of relationship marketing. It is only since 1980s when the need to manage relations with employees and treat them as another group of organisation's stakeholders, and more precisely clients, was introduced.

Employer banding, as all the concepts that are derived from marketing, sets on an assumption, that all the activities performed should be preceded by needs and expectations analyses. The same rule is applicable in case of employer branding. Expectations of employers should be reflected in EB strategies.

There are two main assumptions of the paper. First of all, it seems that at present, employers, especially the ones from the group of blue collars, apart from

\footnotetext{
${ }^{1}$ Dr inż., Politechnika Częstochowska, Wydział Zarządzania, katarzyna.lazorko@wz.pcz.pl
} 
other factors, expect from prosper employers to assure safe work environment. Secondly, as consequence, employers in their external employer branding strategy, include a work safety aspect. To analyse the issue and to verify the above assumptions the concept of employer branding was presented - generally and with emphasis on external employer branding. Consequently, research conducted by the author was discussed and some research on Polish employers and employees were presented.

\section{Genesis and definition of employer branding concept}

Employer branding is one of the most recent concepts in marketing theory. It has also been discussed quite intensively by practitioners of marketing, because of the situation in the labour market that has changed dramatically. Low unemployment rates cause the situation that market has become more employee orientated then employer orientated. The specific circumstance forces organisations to introduce new tools to make recruitment processes more efficient to find employees that help to build effective work teams and keep fluctuation of employees as low as possible. Several concepts was introduced in HR to meet that expectations. But it may be observed that they all derive from the relationship marketing concept. This theory spreads areas of marketing interest and indicates that employees (among others) should be recon as addressees of marketing efforts [2], and their satisfaction influence service awareness and customer orientated behaviour [3]. In the concept of internal marketing, employees are the ones who are supposed to be treated as the first customers of an organisation. All the concepts appearing later - employer branding, HR marketing, etc. can originate from that conceptualisation.

Popularity of employer branding concept can be reckon as a consequence of situation in labour markets, including job seekers behaviour. As research results reveal, employer branding reduce costs of recruitment (companies with a stronger brand declare $43 \%$ decrease in cost hiring), up to $75 \%$ candidates check out employer brand before applying, $94 \%$ of candidates are likely to apply if EB is managed, $91 \%$ candidates find poorly-managed on-line presence damaging to EB, 50\% would not work for enterprise with poor reputation, even if benefits offered are more profitable [4]. But employer branding is the idea that is not orientated just on attracting employees and fill vacancies or to increase the number of applicants, but it is aimed at attracting employees that are highly qualified or skilled and who can contribute to support efforts to reach desired competitive position. Many authors share the opinion that it is not a choice anymore, but necessity [5; 11] "orientated towards attracting the most talented candidates, as well as a method of limiting key employee fluctuation"[6]. Employer branding is also perceived as a source of competitive 
advantage, as positive employer brand strengthens customers' trust [7]. It enables to establish "the identity of the firm as an employer. It encompasses the firm's value system, policies, and behaviours towards the objectives of attracting, motivating, and retaining the firm's current and potential employees" [8]. Martin indicates that employees should identify with their employee to deliver desired results [9], the same point of view is shared by Baruk [10] who claims that present employees transfer their attitude towards employer outside, to the public. It may also be one of the ways to prevent employees from leaving and lowering the rate of fluctuation as a result [11]. Kozłowski indicates that employer branding is based on image of an organisation as an interesting employer among present and potential employees supporting its business goals [12]. More general definition was presented by Malara and Kroik . They indicate that it is a process of placement and promotion of an organisation aimed at targeted group of talents [13].

Employer Value Proposition (EVP) is another concept that may be found in literature when different approaches towards employer branding are researched. It may be defined as "benefits, values and principles related to a given organisation. (...) Companies need an employment value preposition - a statement of why the total work experience at their organisation is superior to that at other companies" [14]. The set "should be adjusted to an employee's individual conditions and take into consideration their current and future (not yet fulfilled) professional and personal needs" [15]. According to specialists from HR Standard, EVP should be included in policy statements and procedures within an organisation. It is a consequence of image that an organisation wish to share among employers and all stakeholders [16]. Companies are more aware of a need to introduce actions that will help to keep employees. The systematic ways to build involvement, organisational culture, etc., has become more frequent [17].

\section{Employer branding tools and models}

As discussed, employer branding is a type of marketing activity, derived from the concept of relationship marketing. It targets current and prospective employees with specific message tailored basing on their requirements and expectations but also organisation's goals, culture and represented system of values. Some definitions narrow down usage of EB only to the group of businesses, but others [13] indicate that it can be applied in wider range of organisations.

Employer branding includes a wide range of activities: internal communication, career paths, training, satisfaction, motivators, studies, integration, value system, internal CSR [12] as well as: employees' testimonials, exposing office and workplace, 
showing perks and benefits, presenting company's culture, presentation of company's events, awards and motivation systems [20].

Generally speaking all the EB activities should base on mutual trust and commitment[5]. Organisations create their own profile basing on characteristic of employees, their values, habits, standards, qualifications and skills [11]. As research indicate most of people searching for work would choose an employer with recognisable and favourable image[18]. $86 \%$ businesses claim that when attractive employer brand is created, talent attraction becomes easier [19].

Many models of EB have been created. They can be divided into: outside-in models (EB external), inside out models (EB internal) and corporation brand models. Each category relates to a specific perception of employer branding (Table 1).

Table 1. Different approaches towards the concept of employer branding

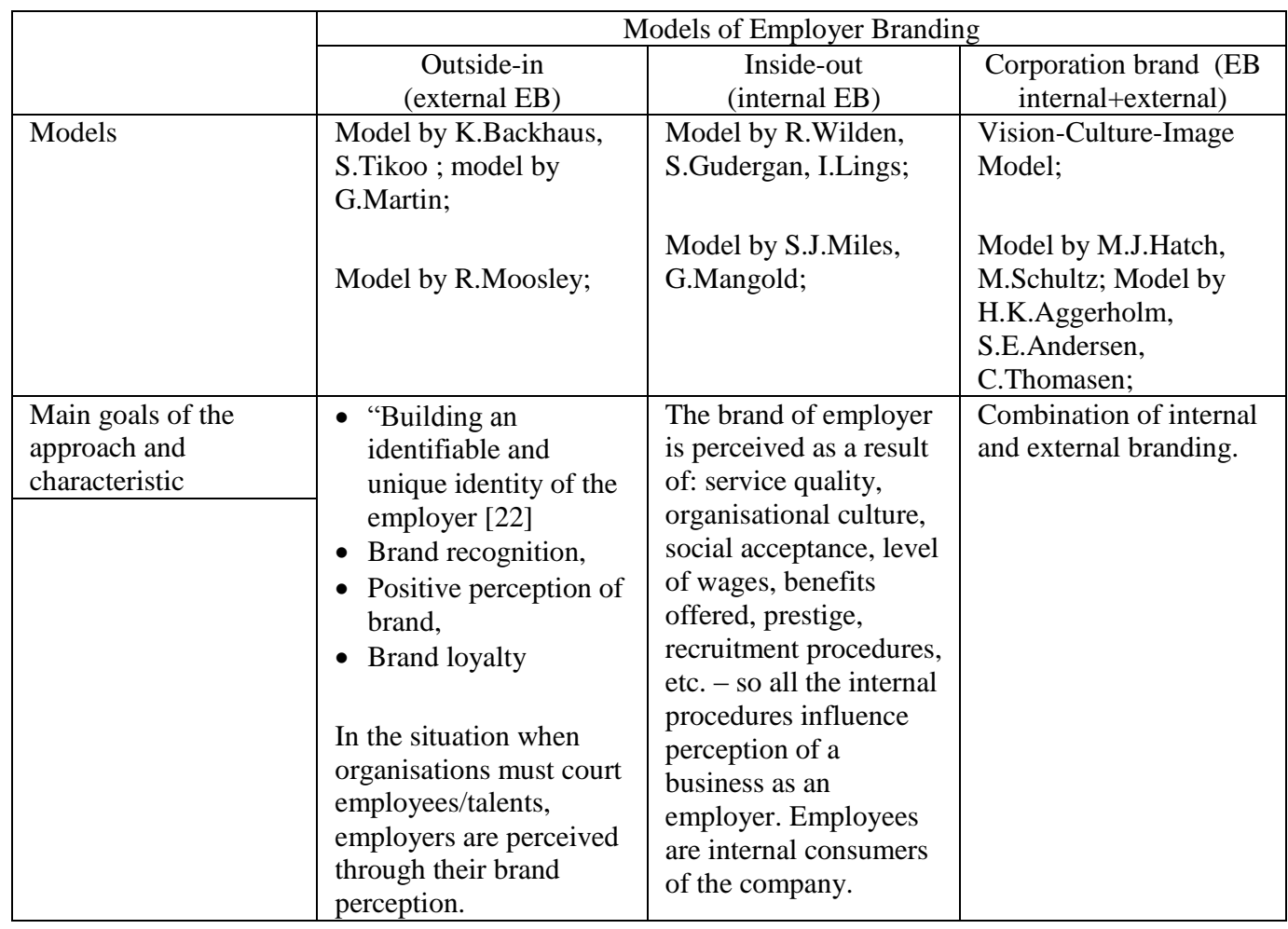

Source: $[12 ; 21 ; 22]$. 


\section{Employer brand content analysis}

For the research the largest 100 businesses were chosen (according to the Wprost ranking of 200 largest entrepreneurships in Poland in 2019) - production ones, employing blue collar staff. The reason for that choice was the statement that can be found in the "CSR w MŚP Report" [23]. The authors of the analyse indicate that the larger the enterprise is the knowledge about social responsibilities of corporation (CSR) is higher [24]. Following that statement the next one can be issued if knowledge of CSR is higher, the employer branding strategies (employers and prosper employees are key element of CSR) are introduced more frequently and their scale (due to possessed resources and large number of employees) should be more professional and of high quality.

The second assumption bases on research on employees expectations. As reports on expectation of labourers in Poland indicate, apart from low level of wages, hard working conditions are main drawbacks of jobs they currently do, and more than $40 \%$ of them consider changing a job - these factors are obviously not mentioned by "white collar" staff [25]. At the same time 55\% of researched, in other study, indicate that would choose the work with lower wages if it was safer [26].

Table 2. The content of "Career" bookmarks (n=100)

\begin{tabular}{|l|l|}
\hline Name & Content-main themes \\
\hline PKN Orlen & diversity of employment possibilities \\
\hline PGNiG & innovation \\
\hline Lotos & training, communication, \\
\hline PGE & R \\
\hline PZU & stability, honesty, innovation \\
\hline KGHM & work-safety, responsibility, bravery \\
\hline Tauron & R \\
\hline Enea & honesty, responsibility, competence and safety \\
\hline PGL & - \\
\hline Energa & R \\
\hline PSE & R \\
\hline Azoty & development, satisfaction \\
\hline JSW & rising competences, knowledge \\
\hline PGG & portal PGG Family \\
\hline LPP & team work \\
\hline Neuca & R \\
\hline Synthos & equity of chances, work-safety, innovations \\
\hline Poczta P. & R \\
\hline Farmacol & webpage "Help us to discover your potential" \\
\hline PLL LOT & R \\
\hline Boryszew & trust, development, competence; testimonials \\
\hline PKP & R \\
\hline P.Gr.Farmaceut. & parts of organisation (departments), benefits, procedures described; R \\
\hline
\end{tabular}




\begin{tabular}{|c|c|}
\hline PKP Cargo & training talents, development, safety \\
\hline PGZbroj & $\mathrm{R}$ \\
\hline G.Maspex & Maspex Kariera program \\
\hline Mlekovita & - \\
\hline SM Mlekpol & $\mathrm{R}$ \\
\hline Stalprodukt & $\mathrm{R}$ \\
\hline Ciech & experience, knowledge transfer, global know-how, development \\
\hline Anwim & - \\
\hline Azoty /Puł. & stability, development, wages, safety \\
\hline Polenergia & - \\
\hline Tele-Fonika & $\mathrm{R}$ \\
\hline Unimot & $\mathrm{R}$ \\
\hline Cedrob & $\mathrm{R}$ \\
\hline Impexmetal & - \\
\hline Onico & brief information about company's approach towards employees \\
\hline Grupa Kęty & work safety as basic element of the CSR strategy \\
\hline Amica $\mathrm{Wr}$ & development, innovation; trainings, $\mathrm{R}$ \\
\hline Polpharma & presentation of EB projects, $\mathrm{R}$ \\
\hline TZMO & $\mathrm{R}$ \\
\hline PSB & - \\
\hline ZE PAK & - \\
\hline Azoty/Police & brief information about employment requirements and work conditions \\
\hline Anwil & $\mathrm{R}$ \\
\hline Famur & work safety and communication - CSR \\
\hline Gobarto & $\mathrm{R}$ \\
\hline Grupa Solid & - \\
\hline Pruszyński & - \\
\hline Wielton & information about presence at work fairs; $\mathrm{R}$ \\
\hline ZGH Bol. & under construction \\
\hline GKR & $\mathrm{R}$ \\
\hline PBG & - \\
\hline Press Glass & R, Facebook profile - Work for Press Glass \\
\hline Kon.Stali & different departments described as well as requirements; \\
\hline Rafako & $\mathrm{R}$ \\
\hline OSM Łowicz & $\mathrm{R}$ \\
\hline Bogdanka & $\mathrm{R}$ \\
\hline KSC & internal EB \\
\hline Black Red White & testimonials, $\mathrm{R}$ \\
\hline Unibep & $\mathrm{R}$ \\
\hline Alumetal & $\mathrm{R}$ \\
\hline Polimex-Mostostal & $\mathrm{R}$ \\
\hline Grupa Nowy Styl & work environment, team work \\
\hline PUH Chemirol & $\mathrm{R}$ \\
\hline Agrolok & presentation of EB programmes, $\mathrm{R}$ \\
\hline Polindus & - \\
\hline Woźniak & - \\
\hline Torpol & development, stability \\
\hline El.Holding & - \\
\hline CNT & - \\
\hline Grupa Fakro & $\mathrm{R}$ \\
\hline
\end{tabular}




\begin{tabular}{|l|l|}
\hline Com40 & work for students, professionals in safe environment \\
\hline Eko-Okna & respect, development, safety, communication, involvement \\
\hline PERN & R \\
\hline Polmlek & R \\
\hline Piątnica & - \\
\hline MPWiK & benefits, stability, new experience \\
\hline Mirbud & R \\
\hline Alchemia & - \\
\hline Get Entra & - \\
\hline Adamed & information about awards; programmes for prosper employees \\
\hline Forte & R, values, firm's presentation \\
\hline Huta Cynku & - \\
\hline Polmax & - \\
\hline Colian & involvement, teamwork, communication \\
\hline Atal & R \\
\hline Mennica Pol. & development, support work safety, high standard \\
\hline Biernacki & R \\
\hline Newag & development, involvement to create innovative products \\
\hline Cersanit & bravery, responsibility, effectiveness, honesty, team spirit, passion \\
\hline Enter Air & team work, development, young staff (EB film), R \\
\hline Drutex & benefits, vacancies \\
\hline Budmat & professionalisation, development; R \\
\hline Indykpol & R - spontaneous application \\
\hline OT Logistics & R \\
\hline Barter & R \\
\hline Apator & $\begin{array}{l}\text { optimal work conditions, work safety, social and financial support of employees, } \\
\text { friendly and inspiring atmosphere at work }\end{array}$ \\
\hline
\end{tabular}

- $\quad$ No applicable webpage

$\mathrm{R}$ - information about recruitment procedures and/or vacanc

Source: own study.

The research was designed to analyse to which extend a content of web pages in part "Career" relates to work-safety issues. The bookmarks "Careers" were chosen, because, just after internet platforms for job seekers and personal contact, they are the third of the most popular ways to find an adequate job offers by candidates [27]. The research was conducted between 12 and 25.10.2019.

The research revealed that only 7 out of 100 the largest businesses in Poland communicate work safety issues in their external branding message - through web pages. 40 web pages contain recruitment information - procedures, job offers. There are some businesses that do not have applicable web page (17) - what is quite a lot, when the scale of their operation is considered (Table 2). 


\section{Conclusions}

Recently the significance of employer branding has increased. The situation has been caused by changes within labour market - low unemployment rates, demographic changes (migration, ageing society), social changes, strategic approach towards branding of an employer is crucial. The concept is also evaluating in two main ways: first of all it is no longer aimed at reaching white collars, as it used to be few years ago, when they were mainly aimed at students and clerks. Moreover employer branding is perceived as more strategic approach as it used to be.

The research conducted on the largest production and service sites in Poland revealed that only $7 \%$ of them communicate work safety issues in their external branding strategy, while for them work environment safety is expected to be even more important. Moreover, when work safety is indicated as an element of employer branding, it is almost never presented as the most important factor, even in CSR strategies of the researched organisations. Most of the analysed businesses have their own CSR strategies and special webpages dedicated to that aspect of their performance. Most of them focus in CSR on ecology, team work, supporting local communities. Consequently employer branding strategies follow that direction. It must be remembered though that "for organisations that want to develop well-rounded CSR strategies, employee health and well-being must be at the centre. Because, if you don't take care of your employees, everything else eventually falls apart" [28].

\section{Bibliography}

[1.] Grant A.M. Harrington B., Gale J., Goler L., Trzy rzeczy, na których naprawdę zależy pracownikom, Harvard Business Review, https://www.hbrp.pl/b/trzy-rzeczy-na-ktorychnaprawde-zalezy-pracownikom/ (Access 14.10.2019).

[2.] Berry L.L. Hensel, J.S. and Burke, M.C., Improving retailer capability for effective consumerism response, Journal of Retailing, Vol. 52-3, pp. 3-14, 1976.

[3.] Gronroos C., From Marketing-mix to Relationship Marketing: towards a paradigm shift in marketing, Management Decision, Vol.32- 2, pp 4-20, 1984.

[4.] 7 Stunning Employer Branding Facts You Need To Know, https://www.socialseeder.com/7-stunning-employer-branding-facts-2019/ (Access 25.10.2019).

[5.] Stuss M. Corporate Social Responsibility as an Employer Branding Tool:The Syudy Results of Selected Companies Listed on GPW, International Journal of Contemporary Managemen vol.17, no 1, pp.249-267, 2018 doi:10.4467/24498939IJCM.18.014.8393

[6.] Struss M. Employer branding: the resuts of the research conducted in selected clothing companies listed on the stock exchange. In: Jaki A., Rojek T., (eds.) Contemporary Issues and Challenges of the Organisation Management Process : Models, Implementation, Interrelations, Wyd. UE, Kraków, pp.111-118, 2017. 
[7.] Bilińska-Reformat K., Stańczyk I., Employer Branding as a Source of Competitive Advantage of Retail Chains, Journal of Management and Business Administration. Central Europe, vol.26, no 1/2018, pp. 2-12, 2018.

[8.] Ainspan N., Dell D., Engaging your Employees through your Brand, The Conference Board, Report No. R-1288-01-RR, April, Conference Board, Washington, D.C., p.502, 2011.

[9.] Martin G., Beaumont P., Doig R, Pate J., Branding: A new performance discourse for HR?, European Management Journal, vol.23, no 1, pp.76-88, 2018.

[10.] Baruk R., Rola marketingu personalnego we współczesnym przedsiębiorstw, Annales UMCS. Sectio H.Oeconomia, (39), pp.211-218, 2006.

[11.] Spychała M., Bartecki T., Brzóska M., Employer Branding - nowoczesne rozwiazanie problemu rotacji pracowników, Zeszyty Naukowe Politechniki Poznańskiej, seria Organizacja i Zarządzanie, nr 79, pp.163-179, 2019.

[12.] Kozłowski M., Employer Branding - budowanie wizerunku pracodawcy krok po kroku, Wolters Kluwer Business, Warszawa 2012.

[13.] Malara M., Kroik J., Dobór, rozwój, motywacja jako pola kształtowania Employer Branding - ocena w świetle badań własnych, Zeszyty Naukowe PWSZ, Nauki Ekonomiczne, Płock 2018, vol 28, pp 417-431 DOI: 10.19251/ne/2018.28(27), 2018.

[14.] Hill B., Tande Ch., Total Rewards. The Employment Value Proposition, http://www.tandehill.com/pdfs/total-rewards.pdf (Access 10.10.2019).

[15.] Dewolska-Opitek A., Bilińska_Reformat K., Employer branding jako determinanta rozwoju sieci handlu detalicznego w Polsce, Problemy Zarządzania, vol.14, nr 1, DOI 10.7172/1644-9584.57.9, s.152-165, 2016.

[16.] https://hrstandard.pl/2010/01/25/employer-branding-2/ (Access 12.10.2019).

[17.] Mikulska A., Employer branding wczoraj i dziś, https://wyzwaniahr.pracuj.pl/employer-branding-wczoraj-i-dzis-wywiad-z-anna-mikulska/ (Access 14.10.2019).

[18.] Aaker D., Building Strong Brands, Free, 2002.

[19.] https://wyzwaniahr.pracuj.pl/nie-kieruj-sie-stereotypami-idz-za-potrzebami/ (Access 14.10.2019).

[20.] https://eventory.cc/blog/top-10-employer-branding-examples-and-how-to-use-themin-your-strategy/ (Access 23.09.2019).

[21.] Szafrański M., Graczyk-Kucharska M., Goliński M., Spychała M., Badanie znajomości marek przedsiębiorstw na potrzeby zewnętrznego employer brandingu - wyniki badań studentów Politechniki Poznańskiej, Przegląd Organizacji, vol.2, pp.21-29, 2019.

[22.] Backhous K., Tikoo S., Conceptualizing and researching employer Branding, Career Development International, vol. 9, pp. 501-517, 2004.

[23.] CSR w MŚP. Pod lupa. Raport 2019, https://www.propertynews.pl/raporty/csr-wmalych-i-srednich-firmach-pod-lupa,77585.html (Access 14.10.2019).

[24.] CSR w matych i średnich firmach 2019, https://interaktywnie.com/biznes/artykuly/biznes/csr-w-malych-i-srednich-firmach-67procent-podmiotow-deklaruje-takie-dzialania-259408 (Access 9.10.2019).

[25.] Na tropie dobrej pracy. Czego szukaja pracownicy fizyczni? Raport Pracuj.pl (Access 04.10.2019).

[26.] BHP: większość pracowników ma ambiwalentny stosunek do bezpieczeństwa pracy, Rzeczpospolita, 8.11.2016. 
[27.] Work Service Barometr Rynku Pracy X, http://www.workservice.com/pl/Centrumprasowe/Raporty/Barometr-Rynku-Pracy (Access 9.10.2019).

[28.] Johansson A., Employee Health and Safety Should be CSR Priorities, https://www.triplepundit.com/story/2017/employee-health-and-safety-should-be-csrpriorities/20336 (Access 12.10.2019).

\title{
BEZPIECZEŃSTWO PRACY JAKO ELEMENT STRATEGII ZEWNETRZNEGO EMPLOYER BRANDINGU
}

\begin{abstract}
Streszczenie: artykuł poświęcony został zagadnieniu employer brandingu. Zawarto w nim wyniki badań własnych przeprowadzonych przez autorkę oraz wyniki z różnych raportów i opracowań dotyczących zagadnienia. Celem badań było stwierdzenia na ile największe polskie firmy, zatrudniające pracowników fizycznych, w swoich strategiach zewnętrznego emploer brandingu wykorzystują zagadnienia związane z bezpieczeństwem pracy. Na dobór dużych firm zdecydowano się ze względu na poziom profesjonalizacji ich działań marketingowych, wynikający ze skali działania i budżetów. Analizie poddane zostały zakładki „Kariera” każdej z firm. Analiza informacji pozwoliła stwierdzić, że firmy w niewielkim stopniu komunikują to, iż dbają o bezpieczeństwo swoich pracowników. Zdecydowana większość z nich posiada strony poświęcone CSR i także tam, w niewielu przypadkach informacje dotyczące bezpieczeństwa pracy są zamieszczane.
\end{abstract}

Słowa kluczowe: employer branding, bezpieczeństwo pracy, marketing wewnętrzny, pozyskiwanie talentów.

Date of sending the publication to the Editor: 07.11.2019

The date of the publication's acceptance by the Editorial Board: 03.12.2019

DOI: $10.30657 /$ qpi.2019.11.02 